\title{
CULTURAL INFLUENCE AND SOCIAL SUPPORT TOWARDS THE DEPRESSION, ANXIETY, AND STRESS LEVELS (CASE STUDY)
}

\author{
Khalifatul Azwin ${ }^{\left.a^{*}\right)}$, Muhamad Fathul Muin ${ }^{b)}$ \\ ${ }^{a)}$ BPS-Statistics Sumbawa, Sumbawa, Indonesia \\ ${ }^{b)}$ BPS-Statistics Papua, Jayapura, Indonesia \\ ${ }^{*}$ Corresponding Author: khalifatul.azwin@bps.go.id
}

Article history: received 29 January 2020; revised 09 February 2020; accepted 16 February 2020

\begin{abstract}
The student's mental health has been a global issue. Students from various regions in Indonesia are more likely to be affected by mental health disorders caused by encountering an unfamiliar environment. Therefore, this study aims to determine the effect of culture shock and social support on depression, anxiety, and stress that is experienced. This research is a cross-sectional study using primary data taken from Polytechnic of Statistics students in the academic year of 2018/2019. The questionnaire refers to DASS-21, MOS Social Support, and 12 cultural concussion items formed by Taft and Mumford. The data obtained were analyzed by the PLS-SEM method. The results found that the prevalence of depression, anxiety, and stress experienced by students are $25.36 \%$, $58.41 \%$, and $17.20 \%$, respectively. In addition, the high occurence of culture shock makes the depression, anxiety and stress experienced increased. Conversely, there was no significant effect between social support and culture shock, depression, anxiety, and stress. The high prevalence of depression, anxiety, and stress experienced by students have a negative impact. All related parties are expected to help overcome students' mental health disorders..
\end{abstract}

Keywords: depression; anxiety; stress; students; PLS-SEM.

\section{INTRODUCTION}

To complete the studies at the university or college level is not easy. Students are faced with various kinds of problems which is interrelated to another and make it more complex. Some of the problems occurred due to being unable to adapt to the new environment, difficulty in allocating time, high lecture demands, and inadequate economic conditions (Johnsson, Zolkowska, \& McNeil, [1]). Because of the many problems that arise, not a few of the students run away from the existing problems and even avoid them and eventually the problems experienced continue to accumulate until they cannot be solved. If this situation is allowed to drag on, it will cause various kinds of psychological disorders (Malla, Joober, \& Garcia, [2]).

Depression, anxiety, and stress are psychological disorders that are often experienced by students compared to other psychological disorders. The American Psychiatric Association [3] classifies mental disorders or psychological disorders into 19 sections, among which there are depressive disorders, anxiety disorders, and stress disorders. According to Teh, et al. [4], depression, anxiety, and stress have high adverse effects both on individuals and society. The disorder can cause various negative impacts so that higher attention is needed to the psychological health of students in order to improve their quality of life (Teh, Ngo, Zulkifli, Vellasamy, $\&$ Suresh, [4]).

Research conducted by Bayram \& Bilgel [5] shows that there should be more attention to depressive disorders, anxiety and stress experienced by students because they can have a large negative impact. They say that high rates of depression, anxiety, and stress among college students have major implications, not only having a negative impact on the health, development, and educational attainment of students but also adversely affect families, institutions, even other people. Argyropoulos et al. [6] said that high levels of depression and anxiety among students had major impacts such as deteriorating quality of life, health, and academic achievement of students. Mahfar et al. [7] said that stress will lead to behavioral impacts including not being enthusiastic about college, being lazy in doing college work, abusing drugs or alcohol and engaging in excessive pleasure.

The high demand for lectures at the STIS Statistics Polytechnic can cause students to experience mental or psychological disorders both mild and severe. This is evidenced by research conducted by Manufoe [8] which found that as many as 41.1 percent of STIS students in the academic year 2010/2011 experienced high stress. Then, the research conducted by Chenata [9] found that as many as 37.0 percent of STIS students in the 2014/2015 academic year experienced high depression. Plus, the latest research conducted by Salu [10] found that as many as 39.0 percent of STIS students in the 2016/2017 academic year experienced distress (academic stress). In addition, every year there must be STIS Statistics Polytechnic students who drop out or do not advance.

When viewed based on the time of the study, psychological disturbances experienced by STIS Polstat students remained high over time. In addition, none of the studies has linked the psychological disturbances of students in this case to disorders of depression, anxiety, and stress with cultural shock and social support. Therefore, in this study, the researchers wanted to find out how much the influence of culture shock and social support on the level of 
depression, anxiety, and stress of STIS Statistics Polytechnic students in the academic year 2018/2019. In addition, researchers also want to find out how much indirect influence social support on the level of depression, anxiety, and stress through the culture shock of STIS Statistics Polytechnic students in the academic year 2018/2019.

According to the World Health Organization, depression is one of the common mental disorders, characterized by persistent sadness, loss of interest in the usual thing to do, coupled with an inability to carry out daily activities that last for at least two consecutive weeks. In line with WHO's opinion, the American Psychiatric Association says that depression is more than sadness, someone who is depressed will lose interest in doing daily activities, lose or gain weight significantly, insomnia or excessive sleep, not powered or weak, difficulty concentrating, feeling very worthless or feeling guilty, and the worst is always thinking about death or thinking about suicide. Depression can be caused by genetic, psychological, and environmental factors. A very common cause of depression is a combination of the three (Bhowmik, Kumar, Srivastava, Paswan, \& Dutta, [11]).

There are many signs of depression that occur and appear on a person. Iyer and Khan [12] summarize some of the symptoms of depression from various sources so that it can be concluded various depressive symptoms that exist such as: sadness, anxiety, feelings of guilt, feeling helpless, insomnia, uncontrolled appetite, loss of enthusiasm, thinking about death, anxiety, irritability, difficulty concentrating, and other physical symptoms. Someone who is depressed does not have to experience all the symptoms of depression. Some people may experience few symptoms and some also experience many symptoms. In addition, the severity of depressive symptoms also varies between individuals.

The American Psychologycal Association [13] defines anxiety as emotions characterized by feelings of tension, thoughts that are always worry, and physical changes such as increased blood pressure, sweating, trembling, dizziness or rapid heartbeat. The American Psychologycal Association adds that a person with anxiety disorders usually has recurring thoughts or worries and avoids certain situations because they are always anxious. Then, American Psychiatric Association in DSM-5 [14] said that anxiety disorders are excessive fear or anxiety, more often associated with muscle tension, alertness and preparation for something that is feared to occur in the future, and behave cautiously or have the habit of distancing yourself from something. The cause of anxiety disorders can be caused by a combination of genetic, environmental, psychological and developmental factors.

Hans Selye [15]explains stress as an indeterminate body response to every change. However, many controversies that occur after that because the definition of stress is considered still narrow and does not include influences from outside oneself. Selye later found that stress is not only negative (distress) but stress can also be positive (eustress) and can motivate someone if it is still in a controlled portion. Losyk [16] said that the stress that occurs in a person can be interpreted as the demands in the individual. Sarafino \& Smith [17] also said that stress is a condition caused by the interaction between an individual and his environment, creating a depressed situation that originates in a person's biological, psychological and social systems.

Several sources of stress according to Papathanasiou et al. [18] namely: biological factors, such as disease, surgery, and pain; chemical factors, such as drugs, toxic substances, and contaminated food / drinks; microbial factors, such as viruses, bacteria, and parasites; psychological factors, such as unpleasant events, separation, death, divorce, feeling useless, and conflict; physical development factors, such as premature birth, disability, and stunting; socio-cultural factors, such as poor interpersonal relationships, social competition, economic difficulties, and rapid changes in social and moral values; and environmental factors, such as unemployment, air pollution, urban life, natural disasters, and extreme weather.

Culture shock is the experience of someone who makes the person confused about the perspective, behavior, and experience that are different from the majority of individuals, groups or communities in their environment (Furham, [19]). Taft [20] divides the culture shock into six aspects, namely difficulty in adapting to a new culture, feeling lost in life when in a new cultural environment, confusion in determining the role and self-identity in a new cultural environment, feeling unaccepted by people in different culture, feel anxious when meeting a new culture, and feel helpless because they cannot adapt to the new cultural environment.

In line with what was said by Oberg, a culture shock could have a negative or positive impact. The negative impacts that can be caused by a culture shock are feeling lost, impatient, apathetic, confusion, irritability, depression, wanting to cry, frustrated, withdrawing, isolated, failing, helpless, afraid, angry, vulnerable, tired, complaining, lacking panic, overwhelmed, homesick, self-doubt, insomnia, disparaging others, pessimistic, difficulty concentrating, despair, physical pain, hostile, rejected, unaccepted, anxious, hostile, distrustful, unaccepted, different, and lonely. While the positive impact if someone can adjust to the shock of culture is feeling happy, satisfied, enthusiastic, creative, capable, expressive, confident, optimistic, accepted, and finding one's identity (Zapf, [21]).

According to Gottlieb, et al. [22], social support is a process of interaction in a relationship to help improve how to overcome problems, self-confidence, ownership, and competence through exchanges that are directly or indirectly felt both in physical and psychosocial terms. Mattson and Hall [23] add that social support that a person receives can be in the form of direct or indirect support. Direct social support is in the form of what is said, done, and given directly to people who need support. While the example of indirect social support is when someone who needs social support believes that he is being given support by someone. In this case, the support in question includes the feelings of someone who needs support when that person needs it. 
Social support is a multidimensional concept that refers to the characteristics and functions of social relationships that are expected to improve physical and mental health (Rodriguez \& Cohen, [24]). Cobb [25] describes social support as a belief in a person that they feel cared for and loved, respected and valued, and feel to be a member of group where they can interact and have responsibilities towards the group. House [26] says that social support is an interpersonal exchange that includes at least one of the following things, namely emotional problems (such as love, love, empathy), instrumental support in the form of goods and services, information about the environment, and assessments relating to oneself. Then, the meaning of social support according to the National Cancer Institute [27] is a network or relationship with family, friends, neighbors, and community that is available when is needed by providing psychological, physical, and financial assistance.

\section{RESEARCH METHODS}

The data in this study were obtained through the results of enumeration by self-enumeration of a number of STIS Polstat students; Level I, II, III, and IV in the academic year 2018/2019 with a population frame from the Academic and Student Administration Section (BAAK) of STIS Polstat STIS.

The population of this research is all students in Jakarta-STIS Statistics Polytechnic academic year $2018 / 2019$. The sampling method used is stratified random sampling with proportional allocation sample with an error rate of 5\%. To avoid non-response, the number of samples used was added by $5 \%$ of the total sample. So, the total population and sample of each level or stratum in this study are as follows:

Table 1

Research Population And Samples

\begin{tabular}{clcc}
\hline No & Level & Total Student & Total Samples \\
\hline 1 & Level I & 593 & 93 \\
2 & Level II & 612 & 96 \\
3 & Level III & 516 & 80 \\
4 & Level IV & 486 & 76 \\
\hline & Total & 2.207 & 345 \\
\hline
\end{tabular}

The measuring instrument used was the DASS-21 questionnaire. With a total of 21 items in which 7 items each were used to measure depression, anxiety and stress. All questions on each item of depression, anxiety, and stress in this study were formed in the same direction using a Likert scale with a value of 1 to 5 where the closer to the value of 5 the higher depression, anxiety, and stress experienced. DASS-forming items (Lovibond \& Lovibond [28]):

1. Depression, consisting of: dysphoria, despair, declining values of life, insulting yourself, losing the spirit of life, unable to feel the pleasure of life, and lazy.

2. Anxiety, consisting of: symptoms of autonomic nerves, the effects of skeletal muscle, situational anxiety, and subjective experience of the influence of anxiety.
3. Stress, consisting of: difficulty relaxing, feeling nervous, easily upset, irritable, and impatient.

As for measuring the culture shock, we used a combination of questionnaires formed by Taft [20] and Mumford [29] to form 12 items used by Pantelidou and Craig [30]. The culture shock question is the difficulty of adapting to a new culture, longing for family and friends to be far away, feeling unaccepted by local residents, wanting to close themselves off from the local environment, difficulty playing a role and acting, finding something shocking and disgusting in the local environment, feeling anxious and unable to overcome problems, feeling anxious and awkward when meeting with local residents, difficulty understanding gestures and facial expressions when interacting with local residents, feeling uncomfortable when seen by local residents, feeling afraid of being cheated and cheated by local residents, and difficulty being polite to the locals. All questions on each culture shock item in this study were formed in the same direction using a Likert scale with a value of 1 to 5 where the closer to the value of 5 then the culture shock experienced is higher.

The survey on social support uses a questionnaire belonging to Sherbourne and Stewart [31]. MOS consists of 19 items. All questions on each item of social support in this study were formed in the same direction using a Likert scale with a value of 1 to 5 where the closer to the value of 5 , the higher the social support obtained. The items forming the MOS Social Support Survey: Emotional support. Informational support, The support provided is real, Positive social interactions, Support affection.

The analytical method used in this research is Partial Least Squares Structural Equation Modeling (PLS-SEM). This method is suitable because it can connect between latent variables that are not directly related (Hair, Black, Babin, \& Anderson [32]). Stages of inference analysis conducted in this study: Determine the Structural Model and Measurement Model, Data Checking, Estimation of the PLSSEM Pathway Model, Evaluation of the Outer Model (Reflective Measurement Model). Evaluate the Inner Model (Structural Model)

\section{RESULTS AND DISCUSSION}

\section{Reflective Measurement Model}

The results of the interim processing showed that there were several violations. Therefore, re-evaluation is done by removing several indicators gradually by eliminating one indicator at a time that does not meet the evaluation of the outer model. The process of eliminating indicators is done by looking at the value of loadings on each indicator. Indicators that have loadings of less than 0.4 are removed from the model. The indicators with loadings between 0.4 and 0.7 are removed from the model if its removal can make the outer model evaluation better or in other words can increase the reliability and validity of the model. Meanwhile, loadings of more than 0.7 are retained in the model. After that, a model that meets the outer model evaluation as shown in Figure 2 is obtained. 


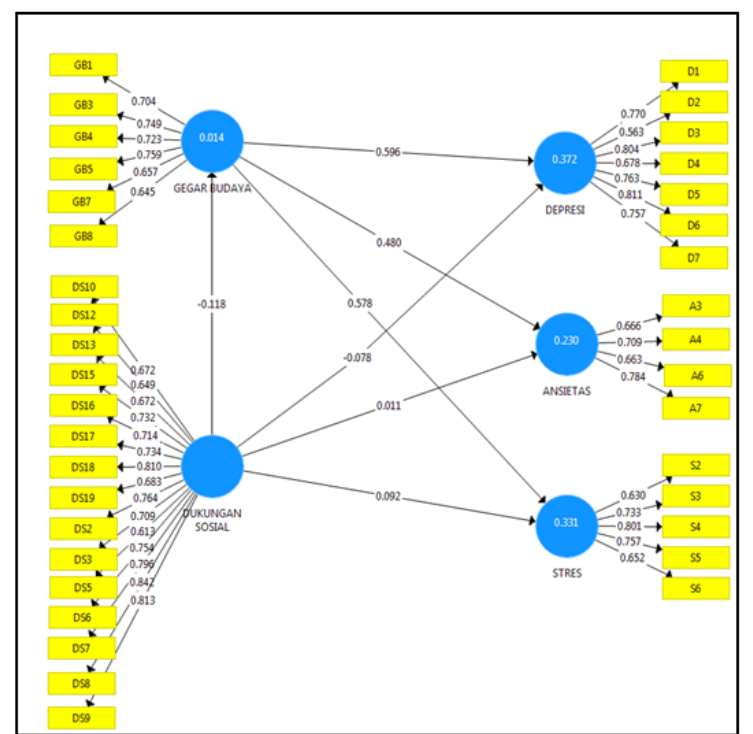

Fig. 1 Output Running Model PLS-SEM after Removing Indicators that Need to be Removed

2. Inner Model Evaluation

1) Multicollinearity: Table 2 shows the VIF between construct predictors. All these values are in the range 0.20 to 5 so that it can be said that there is no multicollinearity between construct predictors.

Table 2.

Vif Output

\begin{tabular}{lccccc}
\hline \multicolumn{1}{c}{ Variable } & Anxiety & Depression & $\begin{array}{c}\text { Social } \\
\text { Support }\end{array}$ & $\begin{array}{c}\text { Culture } \\
\text { Shock }\end{array}$ & Stress \\
\hline Anxiety & & & & & \\
$\begin{array}{l}\text { Depression } \\
\text { Social Support }\end{array}$ & 1.014 & 1.014 & & 1.000 & 1.014 \\
$\begin{array}{l}\text { Culture Shock } \\
\text { Stress }\end{array}$ & 1.014 & 1.014 & & & 1.014 \\
\hline
\end{tabular}

2) Coefficient of Determination $R^{2}$ : Table 3 shows the coefficient of determination and its significance after bootstrapping. Overall, the predictive power of the model is low. Depression ( $p$-value $=0,000)$, anxiety ( $p$-value $=0,000)$, and stress ( $p$-value $=0,000)$, have a significant value, while culture shock $(\mathrm{p}$-value $=0.383)$ has insignificant value. This shows that depression $(=0.372)$, anxiety $(=0.230)$, and stress $(=0.327)$ are influenced by the variables in this study but the effect is low or in other words there are other things outside the model that more influence depression, anxiety, and stressful. Then culture shock $(=0.011)$ is not influenced by social support so there are other variables outside the model that have an influence on culture shock.

Table 3

$\mathrm{R}^{2}, \mathrm{R}^{2}$ Adjusted Dan Bootstrapping $\mathrm{R}^{2}$

\begin{tabular}{lcccccc}
\hline \multicolumn{1}{c}{ Variable } & $\mathrm{R}^{2}$ & $\mathrm{R}^{2}$ Adj. & $\begin{array}{c}\text { Sample } \\
\text { Mean }\end{array}$ & Stdev & t-stat. & $\begin{array}{c}\mathrm{p}- \\
\text { value }\end{array}$ \\
\hline Anxiety & 0.230 & 0.225 & 0.241 & 0.049 & 4.729 & 0.000 \\
Depression & 0.372 & 0.368 & 0.382 & 0.046 & 8.030 & 0.000 \\
Culture & 0.014 & 0.011 & 0.022 & 0.016 & 0.873 & 0.383 \\
Shock & 0.331 & 0.327 & 0.341 & 0.046 & 7.111 & 0.000 \\
Stress & & & & & &
\end{tabular}

3) Effect Size f $f^{2}$ : Tables 4 show how strong the influence of an exogenous variable is on endogenous variables and their significance after bootstrapping. The culture shock variable had a strong and significant correlation with depression $(=0.557 ; \mathrm{p}$-value $=0,000)$, anxiety $(=0.295 ; \mathrm{p}$-value $=0,000)$, and stress $(=0.493 ; \mathrm{p}$-value $=0,000)$. While the social support variable has a weak and insignificant relationship strength to depression $(=0.009 ; \mathrm{p}$-value $=0.544)$, anxiety $(=0,000 ; p$-value $=0.986)$, stress $(=0.013 ; p$-value $=0.541)$, and culture shock $(=0.014 ; \mathrm{p}$-value $=0.405)$.

Table 4

Output F2

\begin{tabular}{lccccc}
\hline Variable & Anxiety & Depression & $\begin{array}{c}\text { Social } \\
\text { Support }\end{array}$ & $\begin{array}{c}\text { Culture } \\
\text { Shock }\end{array}$ & Stress \\
\hline Anxiety & & & & & \\
Depression & & & & & \\
Social & $(0.000)$ & 0.009 & 0.014 & 0.013 \\
Support & 0.986 & $(0.544)$ & & $(0.405)$ & $(0.541)$ \\
Culture & 0.295 & 0.557 & & 0.493 \\
Shock & $(0.000)$ & $(0.000)$ & & $(0.000)$ \\
Stress & & & & & \\
\hline
\end{tabular}

4) Predictive Relevance $Q 2$ : The values of $Q^{2}$ in table 5 above are obtained from the blinfolding results. Based on the table, it is known that all endogenous variables $Q^{2}$ have values more than 0 so it can be said that there is predictive relevance of endogenous variables in the model.

Table 5

Output Q2

\begin{tabular}{lc}
\hline \multicolumn{1}{c}{ Variable } & $\mathrm{Q}^{2}$ \\
\hline Anxiety & 0.104 \\
Depression & 0.187 \\
Social Support & \\
Culture Shock & 0.006 \\
Stress & 0.155 \\
\hline
\end{tabular}

5) Effect Size $q^{2}$ : Table 6 is a $q^{2}$ calculation result to find out the contribution of an independent construct to a $Q^{2}$ dependent variable latent. Based on the table above, it can be seen that exogenous variables of social support have a very small predictive relevance contribution to the endogenous variables of culture shock (0.006), depression (0.004), anxiety (-0.001), and stress (0.004). While the contribution of the predictive relevance of exogenous concussion variables to endogenous variables of depression, anxiety, and stress has values respectively 0.220 (moderate), 0.118 (small), and 0.185 (moderate).

Table 6

Output Q2 (Processed)

\begin{tabular}{lccccc}
\hline Variable & Anxiety & Depression & $\begin{array}{c}\text { Social } \\
\text { Support }\end{array}$ & $\begin{array}{c}\text { Culture } \\
\text { Shock }\end{array}$ & Stress \\
\hline $\begin{array}{l}\text { Anxiety } \\
\text { Depression } \\
\text { Social }\end{array}$ & -0.001 & 0.004 & & & \\
$\begin{array}{l}\text { Support } \\
\text { Culture }\end{array}$ & 0.118 & 0.220 & & 0.006 & 0.004 \\
$\begin{array}{l}\text { Shock } \\
\text { Stress }\end{array}$ & & & & \\
\hline
\end{tabular}


6) Path Coefficient: Interpretation will be meaningful after seeing the value of the effect and the significance of the path coefficient previously tested by bootstrapping. Table 7 shows the value of the direct effect of the overall relationship between constructs and their significance. It can be seen that culture shock is a significant exogenous variable associated with depression (direct effect $=0.596$; $\mathrm{p}$-value $=$ $0,000)$, anxiety (direct effect $=0.480 ; p$-value $=0,000$ ), and stress $($ direct effect $=0.578 ; \mathrm{p}$-value $=0,000)$. This means, the culture shock affects students' depression, anxiety, and stress. Culture shock has the most powerful total effect / direct effect on depression (0.596), then stress (0.578), and finally anxiety (0.480).

Table 7

Direct Effect Exogenous Variable To Endogenous Variable

\begin{tabular}{lccccc}
\hline Variable & Anxiety & Depression & $\begin{array}{c}\text { Social } \\
\text { Support }\end{array}$ & $\begin{array}{c}\text { Culture } \\
\text { Shock }\end{array}$ & Stress \\
\hline Anxiety & & & & & \\
Depression & & & & -0.118 & 0.092 \\
Social & 0.011 & -0.078 & & $(0.131)$ & $(0.171)$ \\
Support & $(0.868)$ & $(0.215)$ & & 0.578 \\
Culture & 0.480 & 0.596 & & & $(0.000)$ \\
Shock & $(0.000)$ & $(0.000)$ & & & \\
Stress & & & & \\
\hline
\end{tabular}

Conversely, social support has a very low and insignificant value with depression $(\mathrm{p}$-value $=0.215)$, anxiety $(p$-value $=0.868)$, and stress $(p$-value $=0.171)$. This means that social support does not affect depression, anxiety, and stress experienced by students. This finding is contrary to the opinion of Barrera [33] who said that someone who has low social support is more likely to experience psychological disorders than people who have high social support.

Then, the relationship between exogenous social support variables and culture shock has no significant relationship (direct effect $=-0.118 ; \mathrm{p}$-value $=0.131$ ) so that it can be said that there is no relationship between social support received by students and the culture shock experienced. This is slightly different from the findings of Pantelidou and Craig [30] where there is a statistically significant negative relationship between the quality of support one received and the level of culture shock experienced.

The value of the total effect indicates that the culture shock has a strong enough relationship to depression, anxiety, and stress. In addition, culture shock also has a positive relationship with depression, anxiety, and stress, which indicates that the higher the culture shock is experienced, the higher the depression, anxiety, and stress disorders that are experienced.

Table 8

Total Effect Exogenous Variable To Endogenous Variable

\begin{tabular}{lccccc}
\hline Variable & Anxiety & Depression & $\begin{array}{c}\text { Social } \\
\text { Support }\end{array}$ & $\begin{array}{c}\text { Culture } \\
\text { Shock }\end{array}$ & Stress \\
\hline $\begin{array}{l}\text { Anxiety } \\
\text { Depression }\end{array}$ & & & & & \\
$\begin{array}{l}\text { Social } \\
\text { Support }\end{array}$ & -0.046 & -0.148 & & -0.118 & 0.024 \\
$\begin{array}{l}\text { Culture } \\
\text { Shock }\end{array}$ & 0.480 & 0.596 & & 0.578 \\
Stress & & & & \\
\hline
\end{tabular}

Which says that the higher the culture shock experienced by a person, the higher the psychological disturbance experienced.

Table 9

Indirect Effect Social Support Variable To Depression, Anxiety, And Stress Variable

\begin{tabular}{lcc}
\hline \multicolumn{1}{c}{ Effect } & $\begin{array}{c}\text { Indirect } \\
\text { Effects }\end{array}$ & P Values \\
\hline $\begin{array}{l}\text { Social Support -> Culture Shock -> } \\
\text { Anxiety }\end{array}$ & -0.057 & 0.274 \\
$\begin{array}{l}\text { Social Support -> Culture Shock -> } \\
\text { Depression }\end{array}$ & -0.070 & 0.262 \\
$\begin{array}{l}\text { Social Support -> Culture Shock -> } \\
\text { Stress }\end{array}$ & -0.068 & 0.260 \\
\hline
\end{tabular}

The relationship between social support and the insignificant cultural shock affects the results of indirect effects (table 9) which is also not significant between social support for depression, anxiety, and stress through culture shock. Where the indirect effect of social support for depression is -0.057 ( $\mathrm{p}$-value $=0.274$ ), the indirect effect of social support for anxiety is -0.070 ( $\mathrm{p}$-value $=0.262)$, and the indirect effect of social support for stress is -0.068 (pvalue $=0.260)$. This means that there is no indirect relationship between social support with depression, anxiety, and stress through the cultural shock experienced by STIS Polstat students.

\section{CONCLUSION}

The paper will not be reformatted, so please strictly keep the instructions given above, otherwise it will be returned for improvement. Please upload your paper in DOC file through the Conference website under Paper Submission menu.

Based on the results of the discussion carried out previously, it can be concluded that culture shock has a strong and positive relationship to depression, anxiety, and stress. The higher the culture shock experienced by STIS Polstat students, the higher depression, anxiety, and stress experienced. In addition, there is no significant relationship either directly or indirectly (through cultural shock) between social support with depression, anxiety, and stress. In other words, the quality of social support received by STIS Polstat students does not affect depression, anxiety, and stress experienced.

The advice given based on this research is that to avoid problems caused by psychological disorders, especially depression, anxiety, and stress. Students need to pay attention to their psychological state by loving themselves; accepting gracefully psychological disorders that occur then turn it into motivation. As for overcoming the culture shock experienced is by not always hanging out with friends from just one area or more opening up with new people in the surrounding environment so that it can make students easier to socialize and can increase social networks. 


\section{REFERENCES}

[1] Johnsson, E., Zolkowska, K., \& McNeil, T. F. 2015. Prediction of adaptation difficulties by country of origin, cumulate psychosocial stressors and attitude toward integrating: A Swedish study of firstgeneration immigrants from Somalia, Vietnam and China. International Journal of Social Psychiatry, 61(2), 174-182

[2] Malla A, Joober R, Garcia A. 2015. Mental Illness Is Like Any Other Medical Illness": A Critical Examination Of The Statement And Its Impact On Patient Care And Society. J Psychiatry Neurosci JPN 40(3):147-150

[3] American Psychiatric Association. 2017. What Are Anxiety Disorders? Retrieved from American Psychiatric Association: https://www.psychiatry.org/ patients-families/anx iety-disorders/what-are-anxietydisorders

[4] Teh, C., Ngo, C., Zulkifli, R., Vellasamy, R., \& Suresh, K. 2015. Depression, Anxiety and Stress Among Undergraduate Students: A Cross Sectional Study. Open Journal of Epidemiology, 260-268.

[5] Bayram, N., \& Bilgel, N. 2008. The Prevalence and Socio-Demographic Correlations of Depression, Anxiety and Stress Among A Group of University Students. Soc Psychiatry Psychiatr Epidemiol, 667672.

[6] Argyropoulos, K., Giourou, E., Dimopoulou, M., Argyropoulou, A., \& Gourzis, P. \&. 2017. Anxiety and Depression among Greek undergraduate Students in the University of Patras. Global Journal of Medicine and Public Health, 6(5), 1-9.

[7] Mahfar, M., Zaini, F., \& Nordin, N. A. 2007. Analisis Faktor Penyebab Stres di Kalangan Pelajar. Jurnal Kemanusiaan, 5(1), 64-74.

[8] Manufoe, J. 2011. Pengaruh Kemandirian, Manajemen Waktu, dan Tipe Kepribadian terhadap Tingkat Stres Mahasiswa Sekolah Tinggi Ilmu Statistik Tahun Akademik 2010/2011. Jakarta: Sekolah Tinggi Ilmu Statistik.

[9] Chenata, Y. 2015. Gambaran Tingkat Depresi Mahasiswa Sekolah Tinggi Ilmu Statistik Tahun Akademik 2014/2015 dan Variabel-Variabel yang Memengaruhinya. Jakarta: Sekolah Tinggi Ilmu Statistik.

[10] Salu, A. 2017. Analisis Stres Akademik Mahasiswa Sekolah Tinggi Ilmu Statistik Tahun Ajaran 20162017. Jakarta: Sekolah Tinggi Ilmu Statistik.

[11] Bhowmik, D., Kumar, K. S., Srivastava, S., Paswan, S., \& Dutta, A. S. 2012. Depression - Symptoms, Causes, Medications and Therapies. The Pharma Innovation, 1(3), 37-51.

[12] Iyer, K., \& Khan, Z. 2012. Depression - A Review. Research Journal of Recent Sciences, 1(4), 79-87.

[13] American Psychologycal Association. 2018. Anxiety. Retrieved from American Psychologycal Association: https://www.apa.org/topics/anxiety/
[14] American Psychiatric Association. 2013. Diagnostic and Statistical Manual of Mental Disorders (DSM5®). Washington: American Psychiatric Pub.

[15] Selye, H. 1936. A Syndrome Produced by Diverse Nocuous Agents. Nature, 138(3479), 32-32. doi:10.1038/138032a0

[16] Losyk, B. 2007. Kendalikan Stres Anda. Jakarta: Gramedia Pustaka Utama.

[17] Sarafino, E. P., \& Smith, T. W. 2014. Health Psychology: Biopsychosocial Interactions. New Jersey: John Wiley \& Sons, Inc.

[18] Papathanasiou, I. V., Tsaras, K., Neroliatsiou, A., \& Roupa, A. 2015. Stress: Concepts, Theoretical Models and Nursing Interventions. American Journal of Nursing Science, 4(2-1), 45-50. doi:10.11648/j.ajns.s.2015040201.19

[19] Furham, A. 2012. Culture Shock. Journal of Psychology and Education, 7(1), 9-22.

[20] Taft, R. 1977. Coping with Unfamiliar Cultures. Studies in Cross-Cultural Psychology, 1, 121-153.

[21] Zapf, M. K. 1991. Cross-Cultural Transitions and Wellness: Dealing with Culture Shock. International Journal for the Advancement of Counselling, 14(2), 105-119. doi:10.1007/bf00117730

[22] Cohen, S., Underwood, L. G., \& Gottlieb, B. H. 2000. Social Support Measurement and Intervention: A Guide for Health and Social Scientists. New York: Oxford University Press.

[23] Mattson, M., \& Hall, J. G. 2011. Health as Communication Nexus : A Service-Learning Approach. Kendall Hunt Publishing: Dubuque.

[24] Rodriguez, M., \& Cohen, S. 1998. Social Support. Encyclopedia of Mental Health, 535-544.

[25] Cobb, S. 1976. Social Support as a Moderator of Life Stress. Psychosomatic Medicine, 38(5), 300-314. doi:10.1097/00006842-197609000-00003

[26] House, J. S. 1981. Work stress and social support. Addison-Wesley: Reading, MA.

[27] National Cancer Institute. 2018. NCI Dictionary of Cancer Terms. Retrieved November 26, 2018, from National Cancer Institute: https://www.cancer.gov/ publications/dictionaries/cancer-terms/def/socialsupport

[28] Lovibond, S. H., \& Lovibond, P. F. 1995. Manual for the Depression Anxiety Stress Scales. Sydney: Psychology Foundation.

[29] Mumford, D. B. 1998. The Measurement of Culture Shock. Social Psychiatry and Psychiatric Epidemiology, 33(4), 149-54. doi: $10.1007 / \mathrm{s} 001270050037$

[30] Pantelidou, S., \& Craig, T. K. 2006. Culture Shock and Social Support - A Survey in Greek Migrant Students. Social Psychiatry and Psychiatric Epidemiology, 41(10), 777-781. doi:10.1007/s00127006-0096-5

[31] Sherbourne, C. D., \& Stewart, A. L. 1991. The MOS Social Support Survey. Social Science \& Medicine, 32(6), 705-714. doi:10.1016/0277-9536(91)90150-B 
[32] Hair, J. F., Black, W. C., Babin, B. J., \& Anderson, R. E. 2013. Multivariate Data Analysis. New York: Pearson Higher Education.

[33] Barrera, M. 1986. Distinctions between social support concepts,measures, and models. American Journal of Community Psychology,14,413-445. 